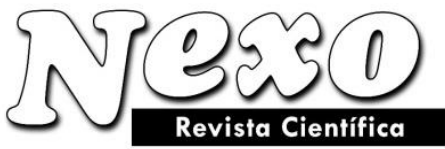

ISSN-E 1995-9516

Universidad Nacional de Ingeniería COPYRIGHT @ (UNI). TODOS LOS DERECHOS RESERVADOS http://revistas.uni.edu.ni/index.php/Nexo https://doi.org/10.5377/nexo.v33i02.10787

Vol. 33, No. 02, pp. 490-510/Diciembre 2020

(c) (i) $€$

\title{
Applying various satellite image processing methods on Aster and Landsat ETM+ data to identify and separate the alteration zones around gold mine of Akhtarchi, Khomein, Iran
}

\section{Aplicación de varios métodos de procesamiento de imágenes por satélite en datos aster y landsat ETM + para identificar y separar las zonas de alteración en torno a la mina de oro de Akhtarchi, Khomein, Irán}

\author{
Alireza Payamani ${ }^{1}$, Behnam Babaei*1 ${ }^{*}$, Saeed Dehghan ${ }^{1}$, Houshang Asadi Harouni ${ }^{2}$ \\ ${ }^{1}$ Department of Mining, Mahallat Branch,Islamic Azad University, Mahallat, Iran. \\ ${ }^{2}$ Department of Mining Engineering, Isfahan University of Technology, Isfahan, Iran. \\ *Corresponding author Email: behnambabaei2006 @ yahoo.com
}

(recibido/received: 11-August-2020; aceptado/accepted: 04-September-2020)

\begin{abstract}
The study area is located $100 \mathrm{~km}$ southeast of Arak and in two structural zones of Central Iran in the north and Sanandaj-Sirjan in the southern part. Regarding its geological structures, the area has become the source of important mines including the Akhtarchi gold mine, Aliabad iron mine, Ochestan feldspar mine, and Dali gold and copper mines. Therefore, promising areas for exploration activities are identified using the analysis of satellite images of ASTER and Landsat ETM + in the region to identify alteration areas. For this purpose, the necessary corrections were applied to the satellite images. Then, to identify the alteration parts related to the gold deposits, different satellite image processing methods of ETM + and ASTER were used. These methods include making a false-color composite, band ratio, Selective Principal Components Analysis (SPCA), Spectral Angle Mapper (SAM) method, Spectral Information Divergence Classification (SID), Endmember Collection Dialog Components (ECDC), and innovative methods such as Principal Component Analysis (PCA) and Spectral Angle Mapper, as well as unsupervised classification methods. In the end, the major alterations in the region were observed. In the obtained images, the prophylitic zone and the phyllic and argillic zones in the region were observed. To introduce the optimal method, the results of the various methods mentioned were compared with each other and with the current situation of the mines. The alteration zones were identified through band ratio and SAM methods and the combined methods with more power. Finally, SAM, 2:1 ratio, and the combined methods were identified as successful methods for more accurate separation of the alteration zones.
\end{abstract}

Keywords: Remote Sensing; ASTER; Landsat ETM+; Crosta; Band Ratio; Spectral Angle Mapper; Spectral Information Divergence Classification; Endmember Collection Dialog Components 


\section{RESUMEN}

El área de estudio se encuentra a $100 \mathrm{~km}$ al sureste de Arak y en dos zonas estructurales del centro de Irán en el norte y Sanandaj-Sirjan en la parte sur. En cuanto a sus estructuras geológicas, la zona se ha convertido en la fuente de importantes minas, como la mina de oro Akhtarchi, la mina de hierro Aliabad, la mina de feldespato Ochestan y las minas de oro y cobre de Dali. Por lo tanto, las áreas prometedoras para las actividades de exploración se identifican mediante el análisis de imágenes satelitales de ASTER y Landsat ETM + en la región para identificar áreas de alteración. Para ello, se aplicaron las correcciones necesarias a las imágenes de satélite. Luego, para identificar las partes de alteración relacionadas con los depósitos de oro, se utilizaron diferentes métodos de procesamiento de imágenes satelitales de ETM + y ASTER. Estos métodos incluyen hacer una composición de color falso, relación de banda, análisis selectivo de componentes principales (SPCA), método de mapeador de ángulo espectral (SAM), clasificación de divergencia de información espectral (SID), componentes de diálogo de colección de miembros finales (ECDC) y métodos innovadores como Análisis de componentes principales (PCA) y mapeador de ángulos espectrales, así como métodos de clasificación no supervisados. Al final, se observaron las mayores alteraciones en la región. En las imágenes obtenidas se observó la zona profilítica y las zonas fílica y argílica de la región. Para introducir el método óptimo, se compararon los resultados de los diversos métodos mencionados entre sí y con la situación actual de las minas. Las zonas de alteración se identificaron mediante métodos de relación de bandas y SAM y los métodos combinados con más potencia. Finalmente, SAM, relación 2: 1, y los métodos combinados fueron identificados como métodos exitosos para una separación más precisa de las zonas de alteración.

Palabras clave: Sensores remotos; ASTER; Landsat ETM +; Crosta; Relación de banda; Mapeador de ángulos espectrales; Clasificación de divergencia de información espectral; Componentes del cuadro de diálogo Colección de miembros finales

\section{INTRODUCCIÓN}

Remote sensing is a method in which objects are measured from a specific distance without actual contact with that object (Harper, Dorothy, 1976). In other words, remote sensing is the process of detecting and monitoring the physical states of a region by measuring reflections and electromagnetic waves from the target. Special sensors collect remote images of the Earth and provide valuable information about the ground surface (The United States Geological Center). Nowadays, remote sensing science, regarding the unique spectral behaviors of minerals, has been used as a new method in mining exploration and geology (Arghavanian et al., 2011). Remote sensing technology is considered as an effective method in mineral exploration and spectral mapping of rock units (Akbari et al., 2015). In recent decades, remote sensing in parallel with sciences such as geophysics and geochemistry has been widely accepted as a standard or criterion in many mining exploration programs, especially in remote and low-precision mapping areas (Alavipanah et al., 2005; Kruse et al., 2003). Remote sensing data can be used to identify states, belts, and mineralization sites because they cover a wide area by multispectral and multidimensional coatings (Gupta, 2003). Remote sensing plays a vital role in the early stages of exploration, especially in the prospecting and potential mapping phase of the mineral in arid and semi-arid regions. Remote sensing tools are widely and successfully used for the exploration of epithermal gold and porphyry copper deposits (Bedini et al. 2009; Azizi et al. 2010). Spectral geology was introduced and flourished with the development of hyperspectral sensors. In 1999, with the launch of the Terra satellite equipped with an ASTER sensor, a breakthrough occurred in the use of this data in mineral geological studies. Considering that the wavelength range of $2-2.45 \mu \mathrm{m}$ of ETM + sensor in Landsat 7 satellite is divided into 5 bands in the ASTER sensor and a large number of minerals in this range have reflectance and absorption spectra, they can be identified using such data.

In this range of the electromagnetic spectrum, there are absorption bands related to minerals containing hydroxyl and carbonate, as well as minerals of the hydrothermal alteration zone including Kaolinite, Chlorite, Alunite, Mica, Jarosite, Dickite, Pyrophyllite, Calcite, and Ankerite minerals. Using image 
spectroscopy allows producing mineralogical maps on the surface in which iron and clay minerals can be distinguished.

Since the ASTER sensor is designed based on geological requirements, the images of this sensor can be used as a powerful tool in the exploration of mineral reserves in the early stages for preliminary mineralogy and preparation of alteration maps with low cost and high accuracy (Tommaso and Rubinstein 2006). Numerous reports have been presented on the use of this sensor data to identify alterations and separation of rock units. Fujisada (1995) and Asadi \& Tabatabai (2007) used band ratio, false-color composite image, and selective principal component analysis (PCA) processing methods to identify alteration ranges in different regions on ASTER images. Gomez et al. (2004) mapped Namibian lithological units using the PCA algorithm on ASTER data. Based on the ASTER remote sensing data, Walfir et al. (2005) applied a selective PCA algorithm for geomorphological mapping of the Amazon coast using ASTER remote sensing data. Ranjbar et al. (2004) used ASTER data in the Sarcheshmeh region to determine hydrothermal alteration zones via the Crosta technique. Neda Mahvash Mohammadi et al. (2012) used different methods for satellite image processing to identify and separate the alteration parts of the Khuni and Kal-e-Kafi regions (Isfahan province). Khalaj Masoumi et al. (2011) identified suitable hydrothermal alteration minerals to obtain areas prone to mineralization of radioactive elements and their relationship with structures using image processing of Terra and Landsat satellites. Masoumi and Ranjbar (2011) applied multispectral ASTER and ETM+ data to determine the altered zones using different image processing methods and thus identified phyllic and propylitic zones.

\section{GEOGRAPHICAL AND GEOLOGICAL LOCATION OF THE STUDY AREAS}

The study area is located at a distance of $100 \mathrm{~km}$ from southeast of Arak and between the longitude of $50^{\circ}$ 00 to $50^{\circ} 30^{\prime} \mathrm{E}$ and the latitude of $33^{\circ} 33^{\prime}$ to $34^{\circ} 00 \mathrm{~N}$. In general, the study area is located in two structural zones of Central Iran in the north and Sanandaj-Sirjan in the south. In the northern part, Late Proterozoic-Paleozoic sedimentary units are outcropped with a northeast-southwest structural trend in the north and west of Mahallat city. Stratigraphically, the Late Proterozoic and Paleozoic units of the northern part are completely comparable to their equivalent units in other parts of Central Iran or Alborz. The oldest rocks outcropped in this area belong to the Late Proterozoic. Among the Paleozoic units, Ordovician, Silurian, and Devonian rocks are not outcropped. Mesozoic rocks are widely spread and Of the Cenozoic rock units, only Eocene, Pliocene, and Quaternary deposits are spread. In the southern part of the study area, a series of metamorphic rocks are outcropped that have been metamorphosed to the amphibolite facies.

Deformation occurs simultaneously with metamorphic events and the formation of multiple foliations, lineament, and folding in them. The presence of multiple intrusive rocks associated with the anatexy phenomenon is another feature of the study area. Based on new studies and matching of the stratigraphic rock of the area with other rocks in the Sanandaj-Sirjan zone, it seems that the source rocks of metamorphic units are Paleozoic in age. As a result of the early Cimmerian event, metamorphic and ductile deformation event has been created in them. Figure1 shows the geological status of the area. 


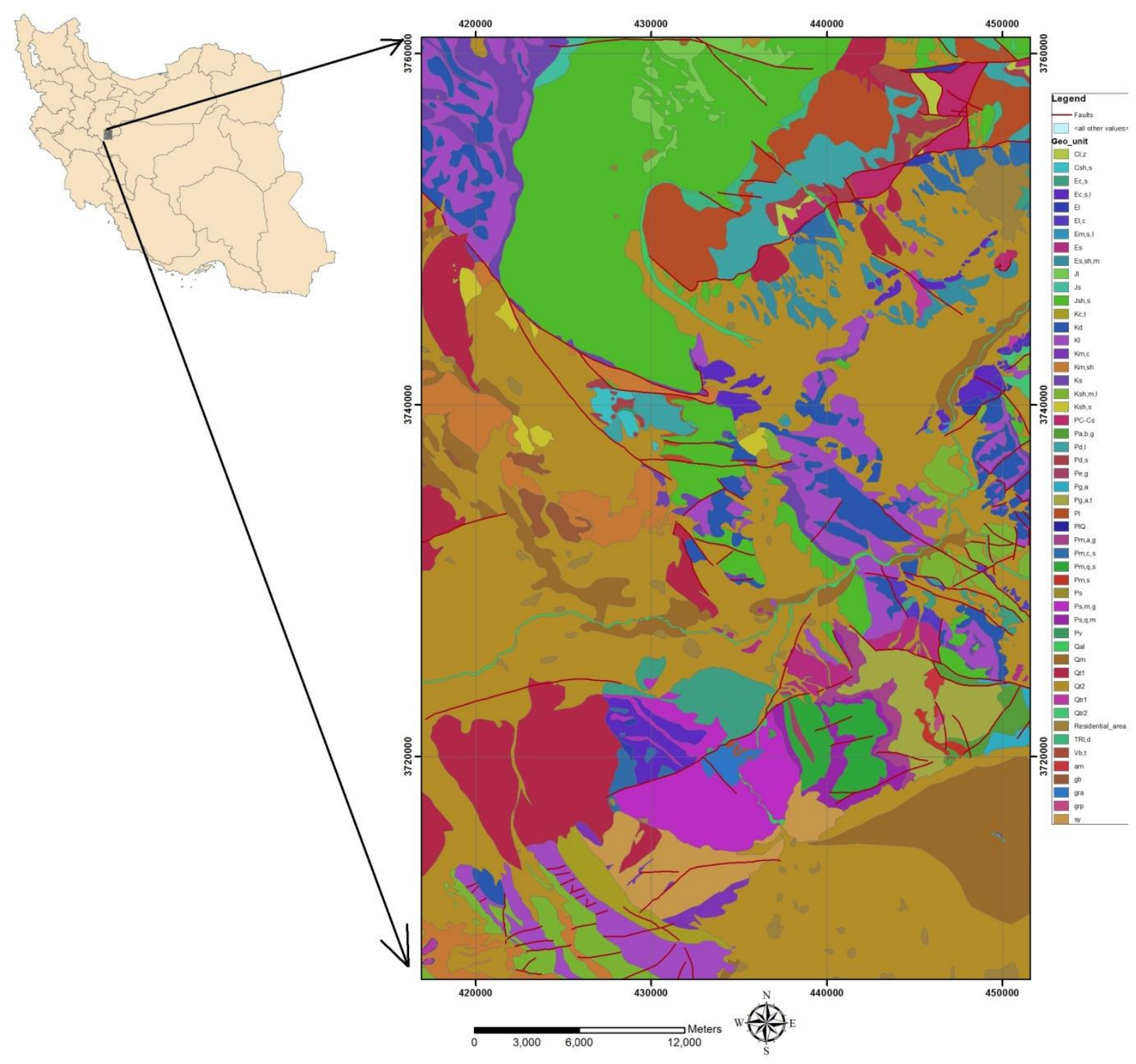

Figure1. Geological map of the study area

\section{METHODOLOGY}

Ninomia (2005), according to the spectral absorption properties of different plants, minerals and rocks defined an indicator for vegetation, mineralogical indices based on the first 9 bands of the ASTER sensor (VNIR and SWIR spectral ranges), and lithological indices based on the infrared thermal range of the ASTER sensor (TIR spectral range). The indices defined by him are shown in Equations 1 to 8 (Ninomiya, Y. and Fu., B., 2005). 


$$
\begin{aligned}
& \text { Stabilized Vegetation Index }(\mathrm{StVI})=\left[\frac{\text { band3 }}{\text { band2 }}\right]\left[\frac{\text { band } 1}{\text { band2 }}\right] \\
& \text { OH bearing altered minerals Index }(\mathrm{OHI})=\left[\frac{\text { band7 }}{\text { band6 }}\right]\left[\frac{\text { band4 }}{\text { band6 }}\right] \\
& \text { Kaolinite Index }(\mathrm{KLI})=\left[\frac{\text { band4 }}{\text { band5 }}\right]\left[\frac{\text { band8 }}{\text { band6 }}\right] \\
& \text { Alunite Index }(\mathrm{ALI})=\left[\frac{\text { band7 }}{\text { band5 }}\right]\left[\frac{\text { band } 7}{\text { band8 }}\right] \\
& \text { Calcite Index }(\mathrm{CLI})=\left[\frac{\text { band6 }}{\text { band8 }}\right]\left[\frac{\text { band9 }}{\text { band8 }}\right] \\
& \text { Quartz Index }(\mathrm{QI})=\frac{(\text { band } 11 * \text { band } 11)}{\text { band } 10 * \text { band } 12} \\
& \text { Carbonate Index }(\mathrm{CI})=\frac{\text { band } 13}{\text { band } 14} \\
& \text { Mafic Index }(\mathrm{MI})=\frac{\text { band12 }}{\text { band13 }}
\end{aligned}
$$

In addition to the ASTER data in Landsat ETM+ data, Pour (Pour, BA, Hashim, M, 2012), Wolf (Wolf 2010), Segal (Segal 1982), and Drury (Drury1987) proposed the following indices for the ETM+ ASTER sensor data.( Equations 9 to 12)

$$
\begin{gathered}
\text { Ferrous Minerals Ratio }=\frac{S W I R}{N I R} \\
\text { Clay Minerals Ratio }=\frac{S W I R 1}{S W I R 2} \\
\text { Iron Oxide Ratio }=\frac{\text { Red }}{\text { Blue }} \\
N D V I=\frac{(N I R-R e d)}{(N I R+R e d)}
\end{gathered}
$$

Where for Landsat ETM+ satellite data, b5 $=\mathrm{SWIR} 1, \mathrm{~b} 7=\mathrm{SWIR} 2, \mathrm{SWIR}=\mathrm{b} 5, \mathrm{NIR}=\mathrm{b} 4, \mathrm{Red}=\mathrm{b} 3$, and Blue $=\mathrm{b} 1$.

The NDVI1 coefficient shows the vegetation rate in the area. To minimize the effect of vegetation on the data, the data integration method was used and the effect of vegetation was removed.

To better separate the alteration zones, the modified images were processed. These processes include the false-color composite image, band ratio, PCA, and spectral angle mapper method. The operation of these methods is briefly described below.

False-color composite image: Experimental analyzes have shown that to observe altered areas, images with band composition of 4-6-8, 4-5-7, and 7-2-9 are the most suitable color combinations to identify alteration areas in most deposits, especially porphyry copper and epithermal gold (Azizi et al., 2010; Blocki and Pourmirzaei, 2009).

\subsection{Band Ratio:}

1- Normalized Difference Vegetation 
Band ratio is a multispectral image processing method that involves dividing the pixels of one image or spectral band by the corresponding pixels of that image or other band. The main advantage of this method is that it transmits the color or spectral properties of the image without considering the changes in landscape exposure conditions caused by topographic changes, and emphasizes the color content of the data (Sabins, 1999). Before performing any analysis to separate different rock units and alterations, the vegetation of the area should be identified, this is because of the presence of different types of clays in the soil of these areas. This issue causes the interference of these areas with alteration zones (Asadi Harouni, 2006). In addition to NDVI, to determine the vegetation, the band ratio 2.3 is used. Given the spectral characteristics of the index minerals in each type of alteration, the band ratios can be defined to determine the alteration zones. To detect, Propylitic, phyllic, and argillic alterations, the index minerals of these alterations and their standard diagrams can be used. According to the standard reflection spectrum of the propylitic alteration index minerals (chlorite), these minerals are irradiated in bands 9 and 7 and adsorbed in band 8 due to the presence of $\mathrm{Mg}-\mathrm{OH}$ bond. Velosky et al. (2003), enhanced propylitic and Gossan alterations related to the mineralization of massive sulfide deposits in southwestern Saudi Arabia. The band ratios and the main false-color composite used in this study are 2.4, 5.4, and 6.5. Xu et al. (2004) identified mineralization zones with hydrothermal alteration around hydrothermal gold deposits using ASTER sensor data in northeast China. They used the PCA technique and band ratios of 2.3, 1.4, and 6.4 to separate vegetation, iron oxides, and clay minerals, respectively.

\subsection{Principal Component Analysis (PCA):}

The PCA method is probably the oldest and best-known method in multivariate analysis. The main purpose of using PCA is to reduce the size of the data set while preserving the information contained in them (Soe et al. 2005). For each principal component, the corresponding image is calculated from an Eigenvector.

The numerical values of the principal component image are calculated using the numerical values in the primary images and the components of the Eigenvectors are calculated as Equation 13:

$$
P_{k}=\sum_{i=1}^{n} a_{i k} D N(i)
$$

Where $\mathrm{Pk}$ is the numerical value of the desired pixel for the kth principal component, DN (i) is the numerical value in the ith band for the desired pixel, aik is the value of the load element obtained from the Eigenvector of the kth component in the ith band. So, for each principal component or corresponding Eigenvector, an image is obtained that represents the variability in the direction of that vector (Vincent, RK, 1997). Crosta and Moore (1989) used a PCA-based technique to map rocks and minerals containing iron oxide and hydroxides related to the sulfide metal masses in the Granite-Greenstone belt using TM satellite data (Azizi et al., 2007). So, it can be ensured that phenomena such as vegetation will not appear in the mapping of the target minerals, and also the spectral information of the target phenomenon (alteration minerals) will be displayed with the help of a special principal component (Crosta and Moore, 1989). The condition for selecting suitable PCs is that in Eigenvector matrices, the bands related to the adsorption and reflection of the target minerals have the highest values at the same time, as well as these values are non-symbolic (Crosta and De Souza Fliho, 2003).

\subsection{Spectral Angle Mapping (SAM):}

Spectral angle mapper is an automatic algebraic method that calculates the similarity of a spectrum between the spectrum of each pixel and the reference spectrum. The similarity between these two spectra is the mean angle of the two spectra, where each spectrum corresponds to a vector in a space with dimensions equal to the number of bands.

This method is not sensitive to pixel brightness. The algorithm representing the spectral angle calculates the similarity between a net spectrum $t$ and a reference spectrum $r$ for $n$ bands using the arc cosine of the dot product of the two spectra, as follows: 


$$
A=\sum_{i=1}^{n} t_{i} / \sqrt{\sum_{i=1}^{n} t_{i}{ }^{r} \sum_{i=1}^{n} r_{i}{ }^{r}}
$$

So, its output for each pixel is the angular distance between the two spectra (expressed in radians) and varies from 0 to 2 . Therefore, the spectrum that has the least angle with the net member will be the most similar (Kruse, F. A. 1999).

\subsection{The use of Spectral Information Divergence (SID) Classification}

Spectral Information Divergence (SID) is a spectral classification method that uses divergence measurements to match pixels to reference spectra. As the divergence decreases, the similarity of the pixels increases. Pixels that are larger than the visual threshold are not classified. The spectra used by the SID can be obtained from ASCII files or spectral libraries, or they can be extracted directly from an image (Envi 5 help).

\subsection{The use of Endmember Collection Dialog Components (ECDC) method}

The ECDC contains a table of spectra that allows you to observe and edit the properties associated with each of the spectra listed (Envi 5 help).

\section{DATA PREPROCESSING}

The data used in this study are level 1 ASTER data collected in 2001 on which geometric corrections were made in the UTM 39 zone based on the WGS-84 elevation. As satellite images are upgraded to higher spectral resolution, they are more affected by atmospheric effects. So, atmospheric correction of images is essential. This is also true for ASTER images, which have a relatively higher spectral resolution compared to ETM images. Since the complete elimination of radiometric error and the creation of an accurate reflection, the image requires a lot of environmental and atmospheric parameters, and this information was not available for the ASTER and ETM images, so to enhance the spectral effects, the internal average relative reflection (IARR) method was used.

\section{PROCESSING OF SATELLITE DATA}

Band ratios can be defined according to the spectral characteristics of index minerals in each type of alteration to determine the alteration zones. According to the standard reflection spectrum of the propylitic alteration index minerals (chlorite), these minerals are irradiated in bands 9 and 7 and adsorbed in band 8 due to the presence of $\mathrm{Mg}-\mathrm{OH}$ bond. According to the diagram of the reflection spectrum of the phyllite and argillic alteration index minerals, these minerals are adsorbed in bands 5 and 7 and radiated in bands 6 and 5, respectively. Therefore, to identify regions with alteration, the band composition of 4-6-8, 7-2-9, and 4-5-7 was used. Suitable band ratios for detecting areas with these alterations are shown with a positive effect (bright pixels). Figure 2 shows the images obtained from the band ratio method. To identify regions with alterations the band ratios of 2/1,3/2, and 7/9 were used. Figure. 3 shows the band ratios. 


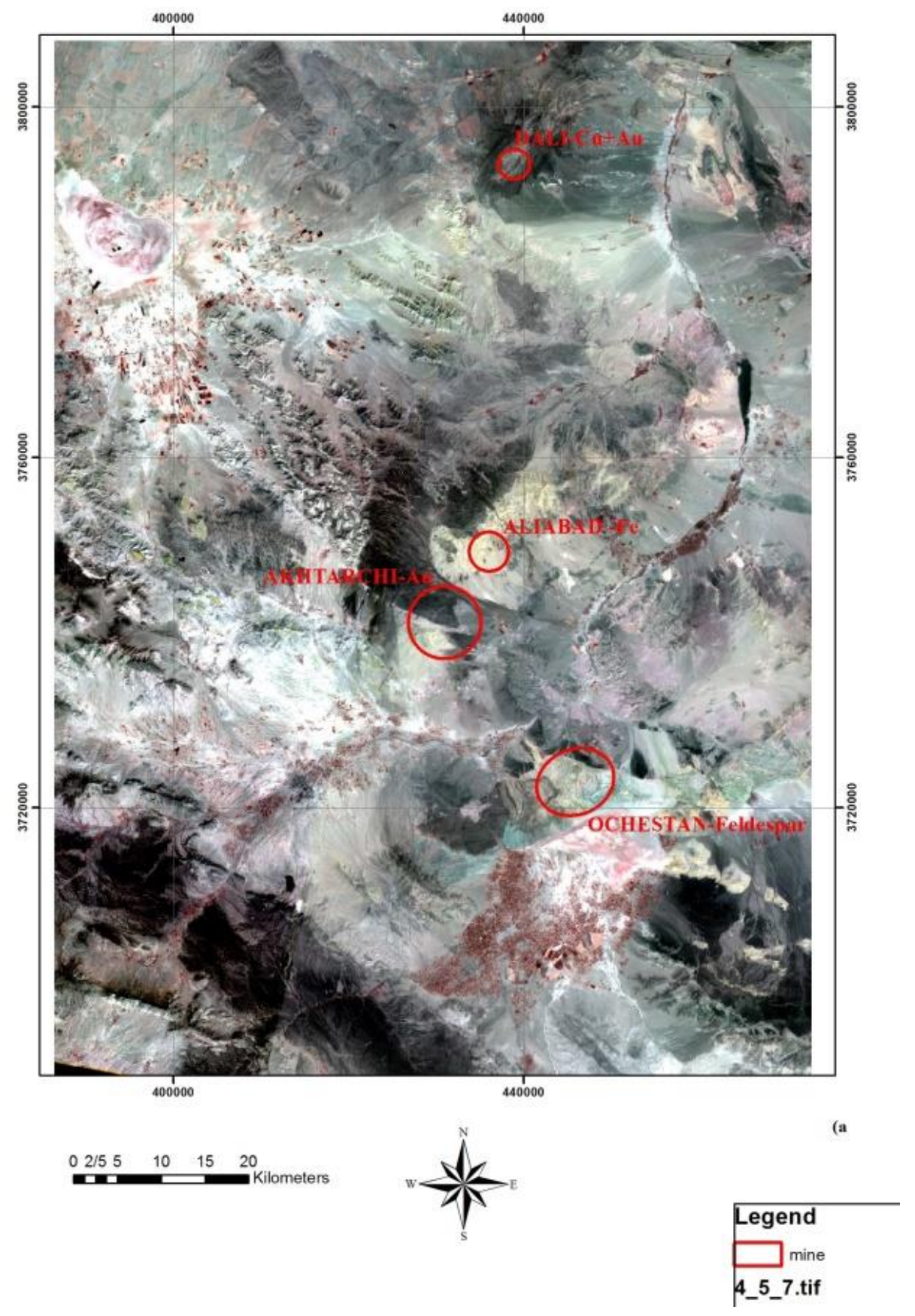




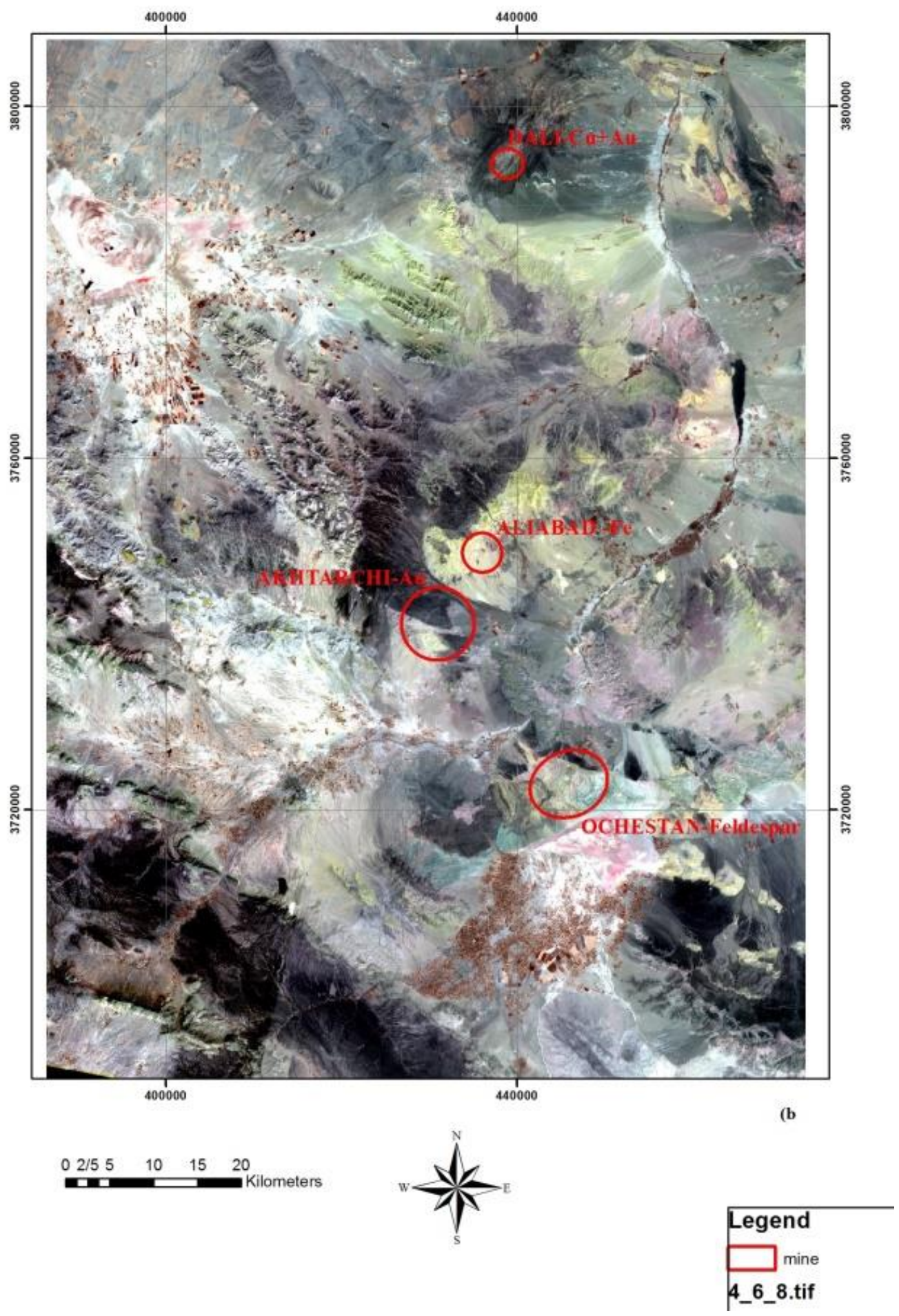




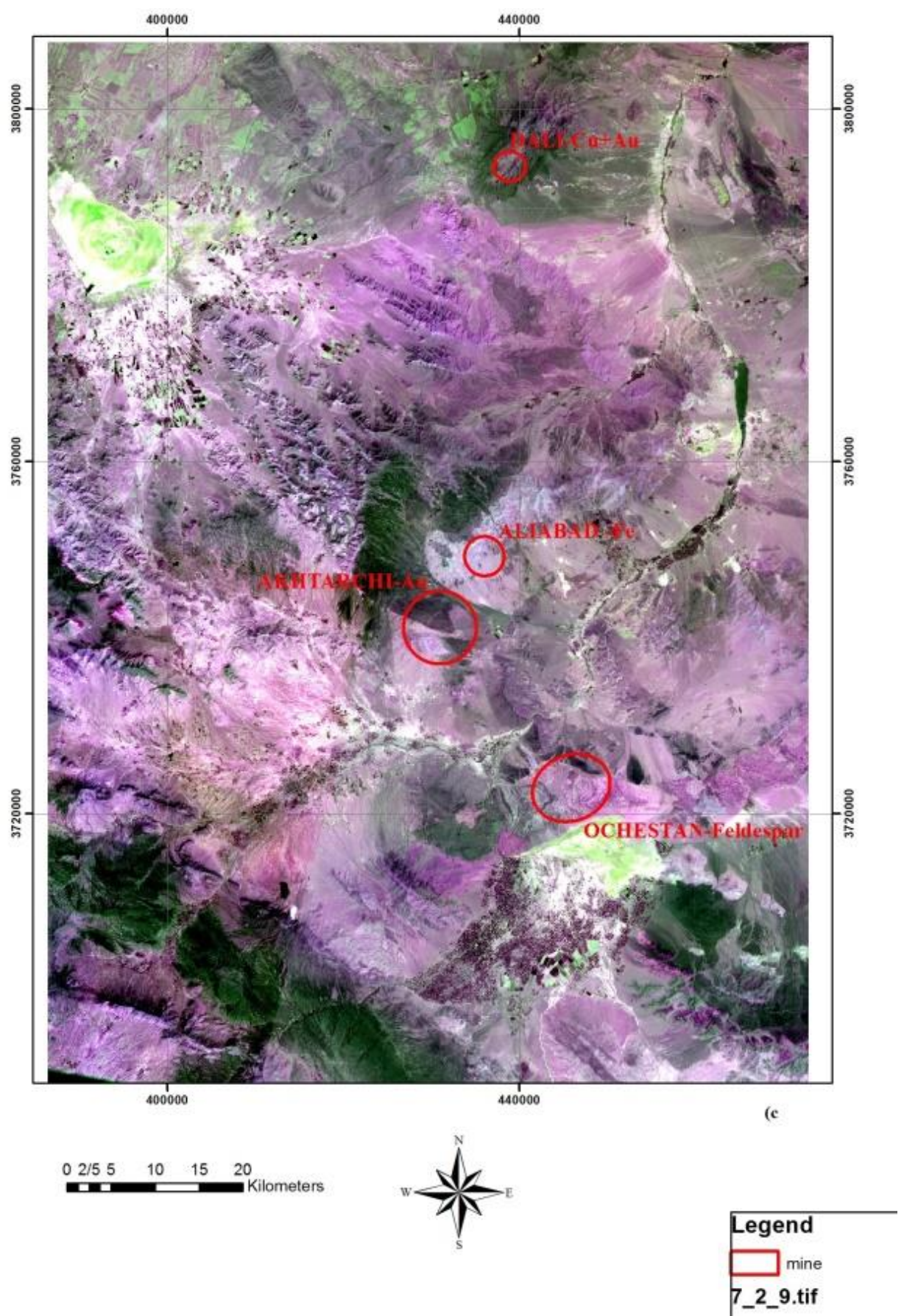

Figure2. A) RGB 457 false-color image of the study area. In this figure, which the color composite of the study area is 4-5-7, pink and white colors indicate alteration areas.

B) The image obtained based on the RGB 468 false-color composite is shown for the study area. In this image, areas with propylitic alteration are green, areas with sericite alteration are pink, and areas with argillic alteration are yellow. This is because of the high reflectivity of alunite, kaolinite, and muscovite minerals in band 4 compared to bands 6 and 8 .

C) RGB 729 false-color combination. In the above image, the propylitic alteration, phyllic alterations are shown in green. 


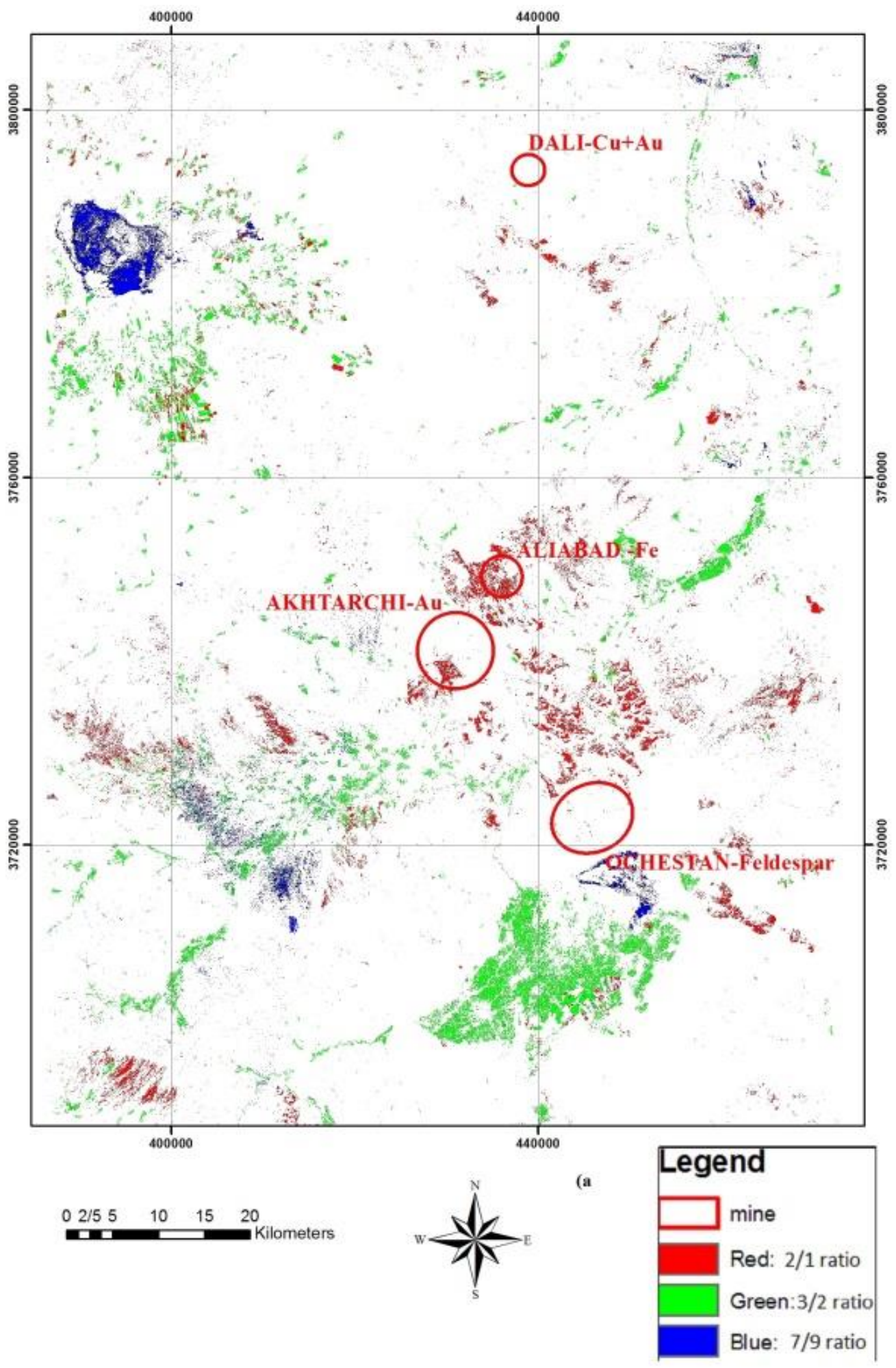




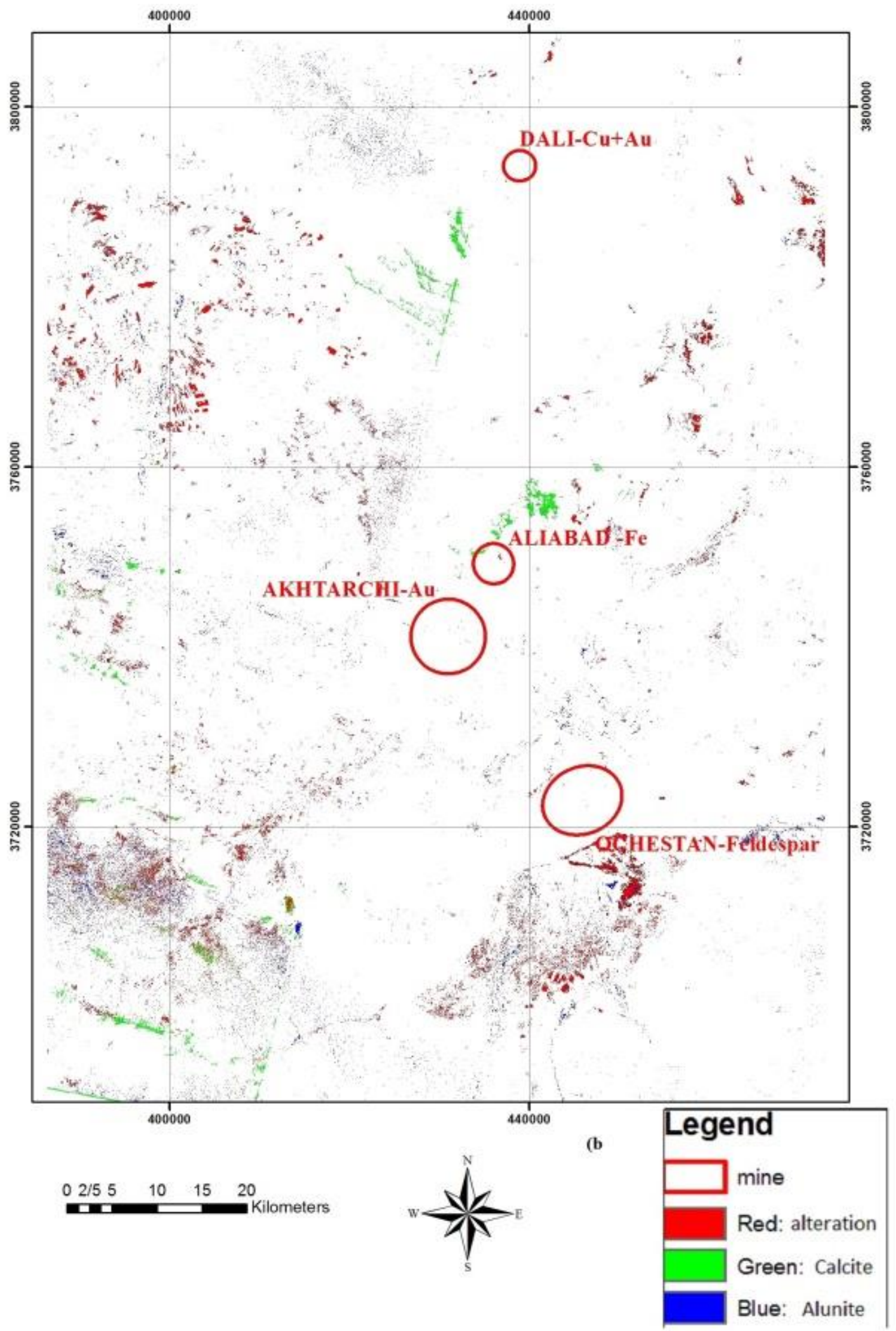




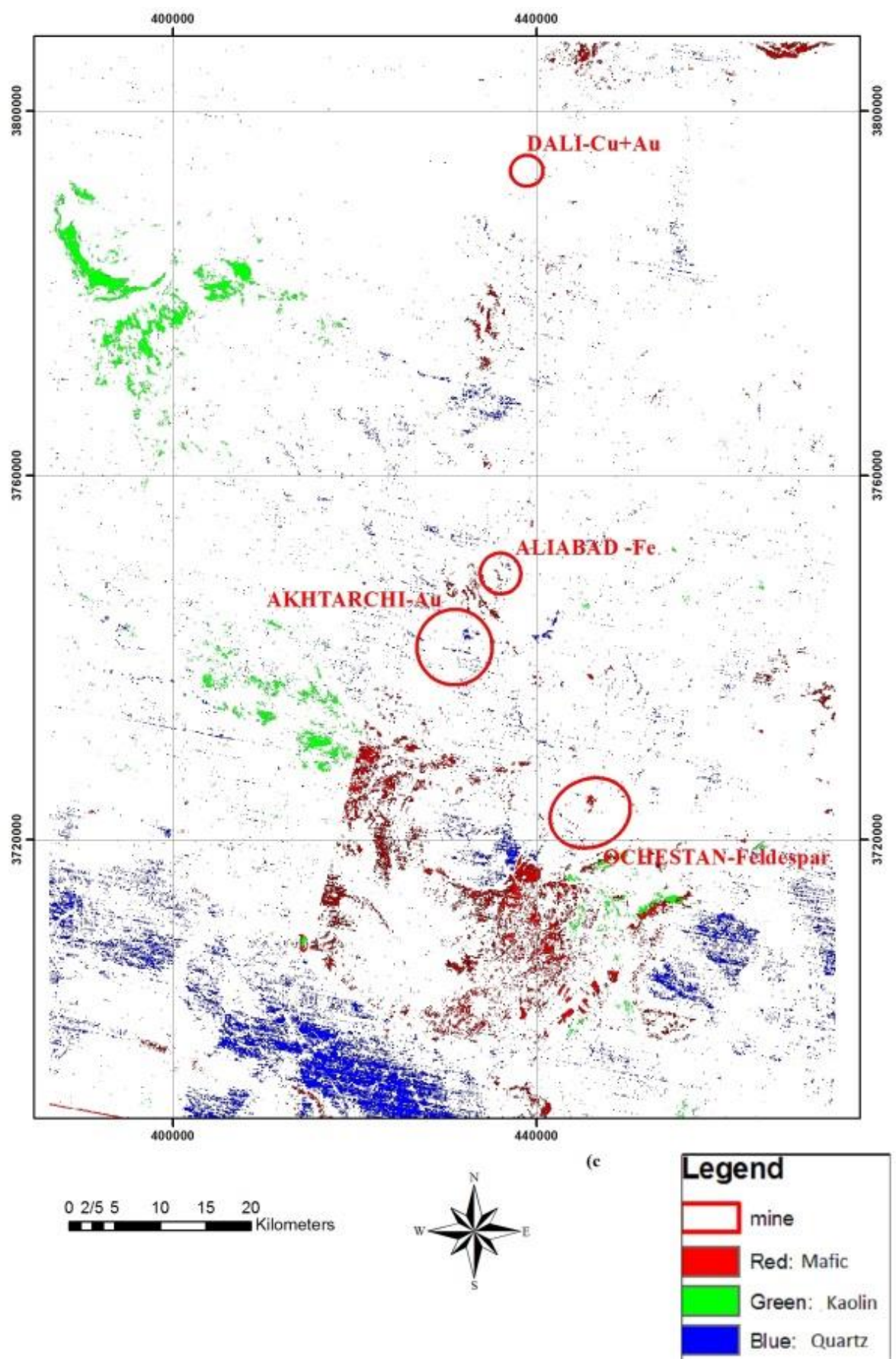

Figure 3. A) The band ratio of $2 / 1$, which indicates iron oxides in red. Band ratio of $3 / 2$, which indicates vegetation in green. Band ratio of $7 / 9$, which indicates alteration areas in blue.

B) The composition of the bands (4/6)*(7/6), which indicates the altered areas in red. Composition of bands $(7 / 8) *$ $(7 / 5)$, which indicate areas with alunite in blue. Composition of bands $(9 / 8) *(6 / 8)$, which indicate areas with calcite in green.

C) The ratio of bands (12/13), which indicates the areas with mafic minerals in red. C) Composition of bands $(10 * 10) /(11 * 11)$, which represent areas with quartz in blue. Composition of bands $(8 / 6) *(4 / 5)$ which indicate areas with kaolin in green.

In addition to the ASTER data, ETM + data were also used and the results are given in the following figures. To prevent errors, the effect of vegetation was removed using the data integration method. 


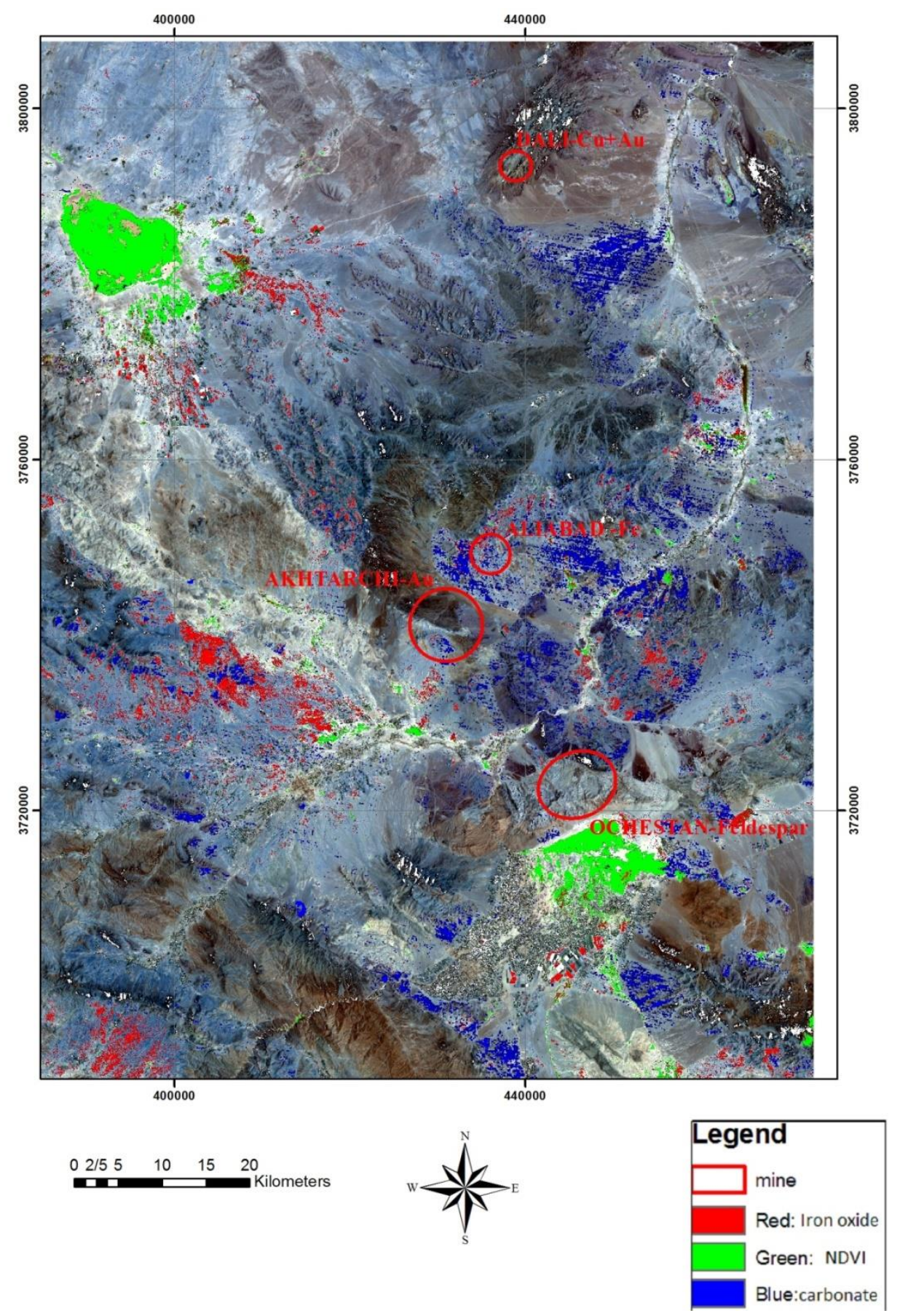

Figure 4. Band composition (b4-b3) / (b4 + b3) in Landsat ETM + satellite data, which is known as NDVI coefficient, and in Landsat ETM + satellite data represents vegetation (green). The band ratios of b5/ b4 and b3/ b1 in the Landsat ETM + satellite data which represent the number of ferrous minerals in red.

Figure $5 \mathrm{~A}, 5 \mathrm{~B}$, and $5 \mathrm{C}$ present the color image of the spectral angle classification of the study area. The intended angle is 0.05 for argillic, phyllic, and propylitic. Red and green colors indicate regions of alteration. 


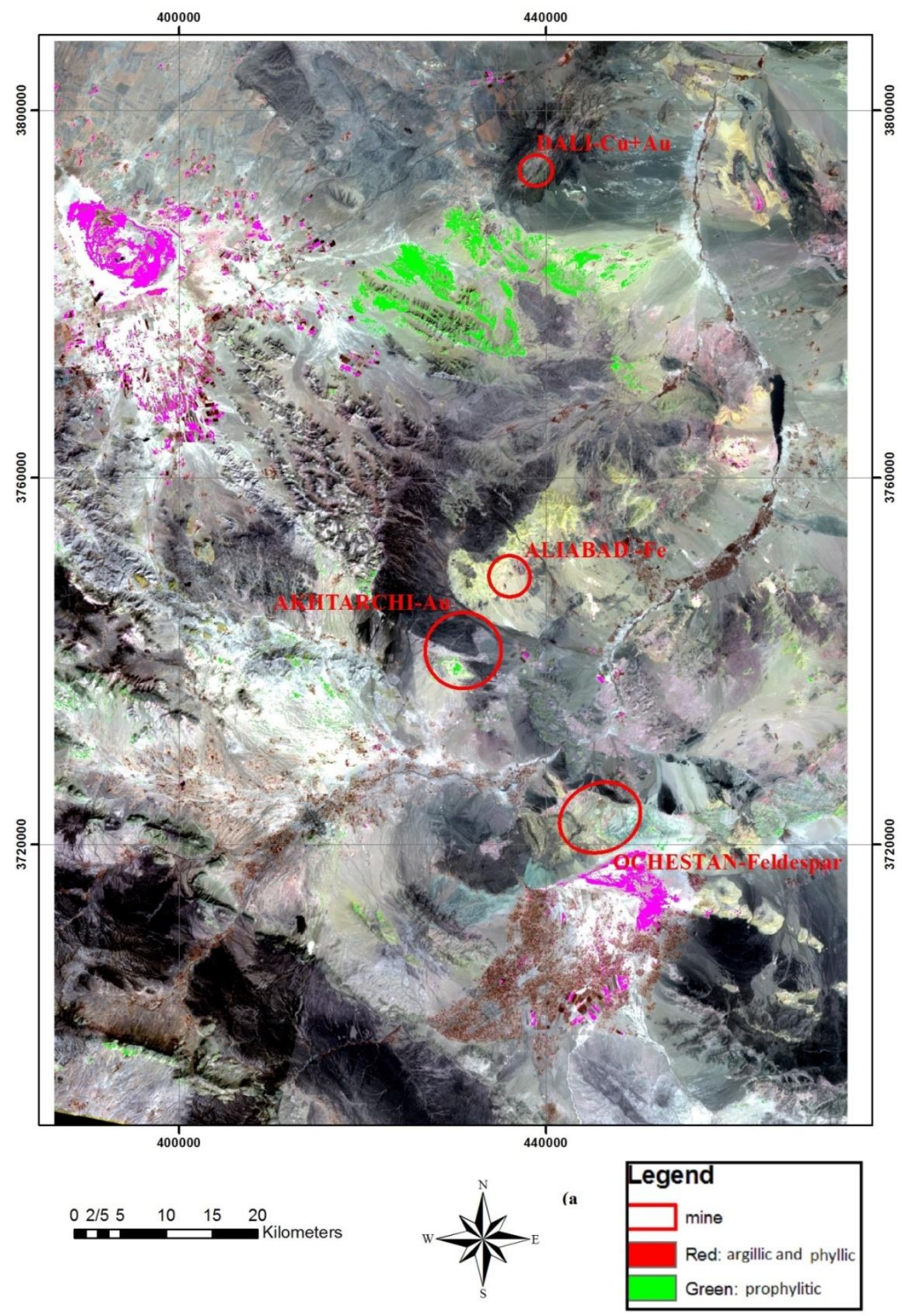




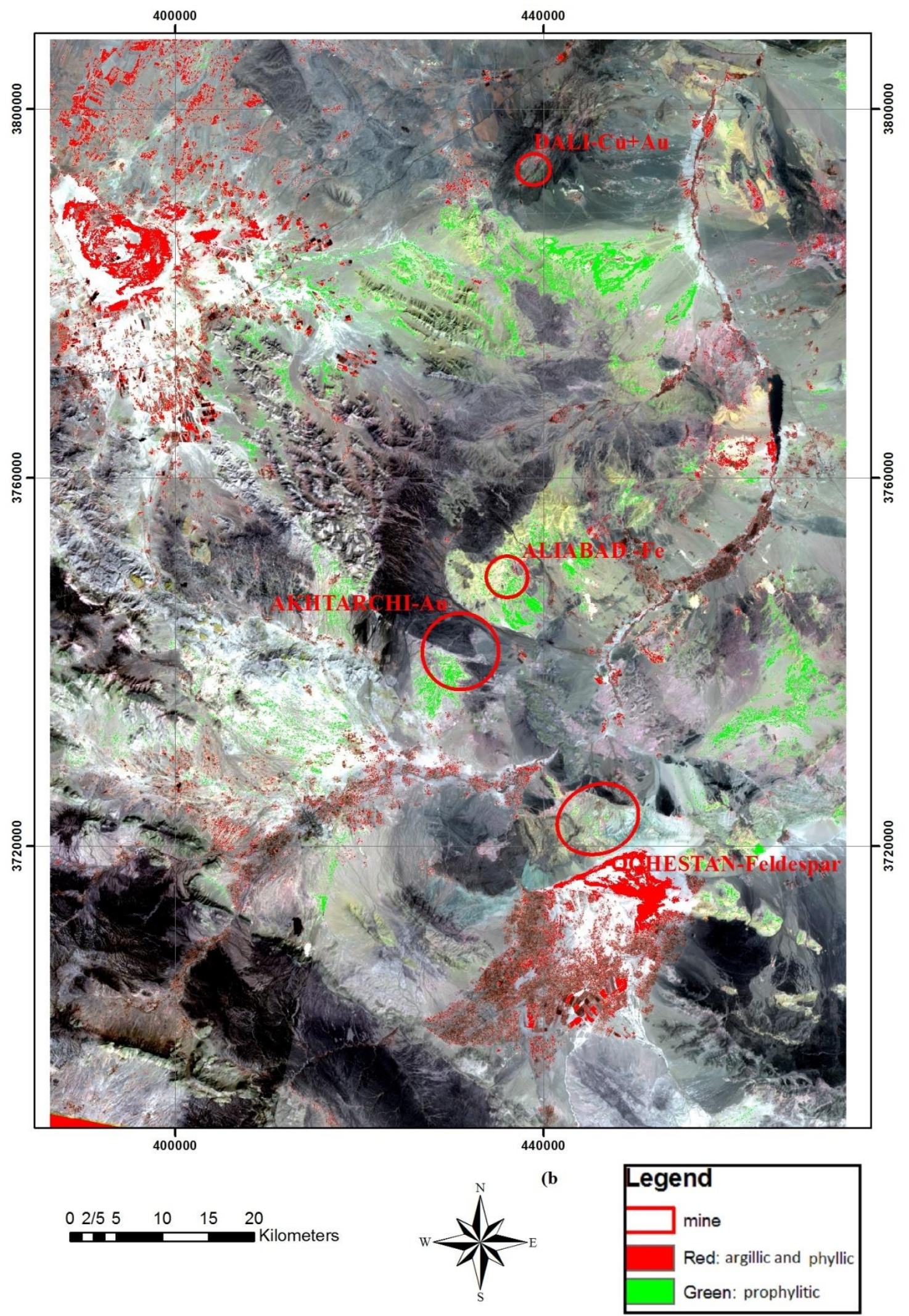




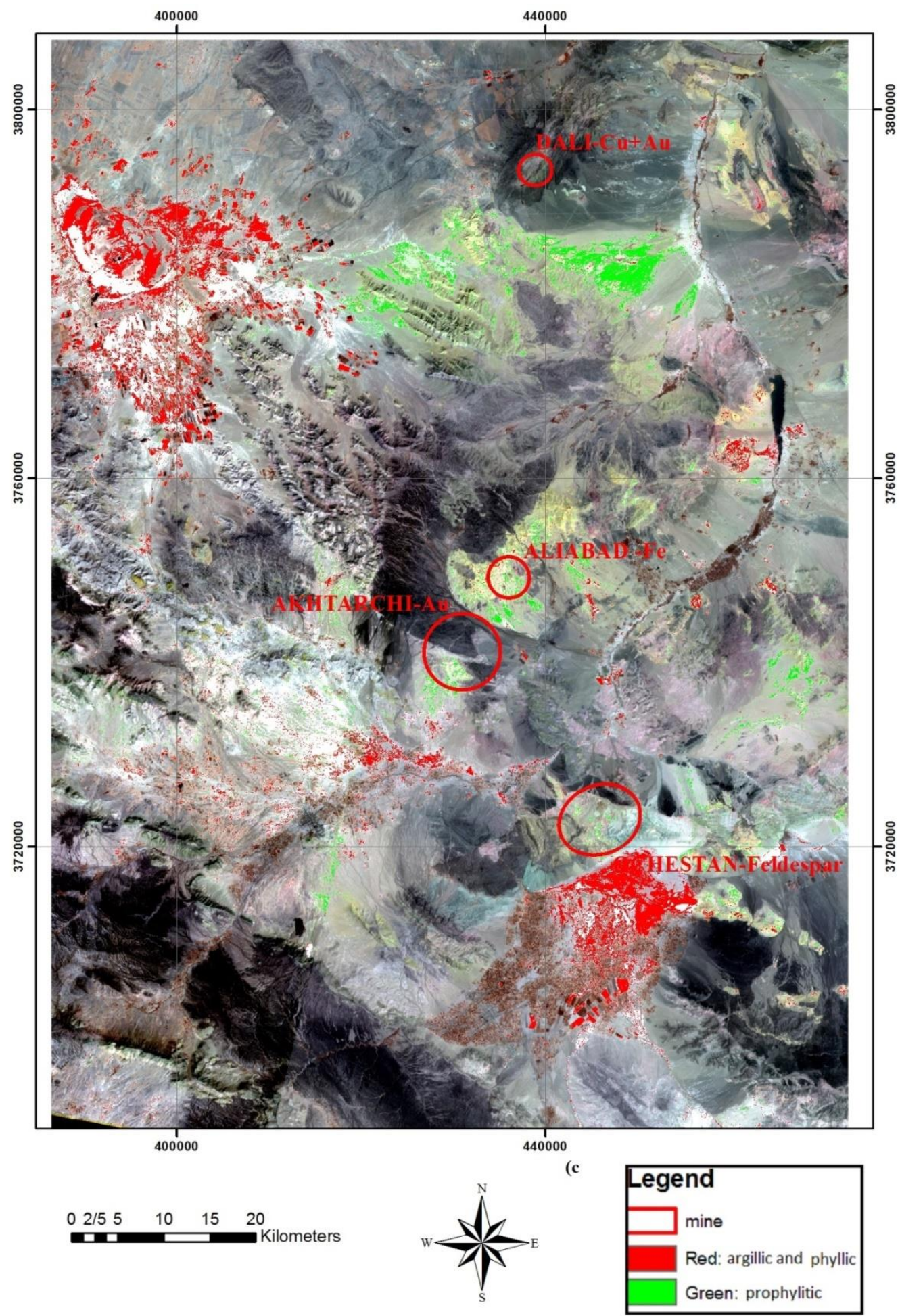

Figure 5. A) SAM image, B) SID image, and C) ECDC images of the colored zone in the spectrum angle classification; green color denotes the propylitic zone and violet color shows argillic and phyllic zone.

To perform the Crosta method, 14 components were used. According to the investigation of the matrix of Eigenvalues of propylitic zone, PC5 is selected as a suitable PC based on the PC 
selection condition, and the maximum difference between bands 7 and 6 . Images of propylitic, argillic, and phyllic alterations related to mineralization in the study area are shown in the following figure. Bright pixels indicate argillic, phyllic, and propylitic alterations. The image obtained by PCA method is shown in the following figure:
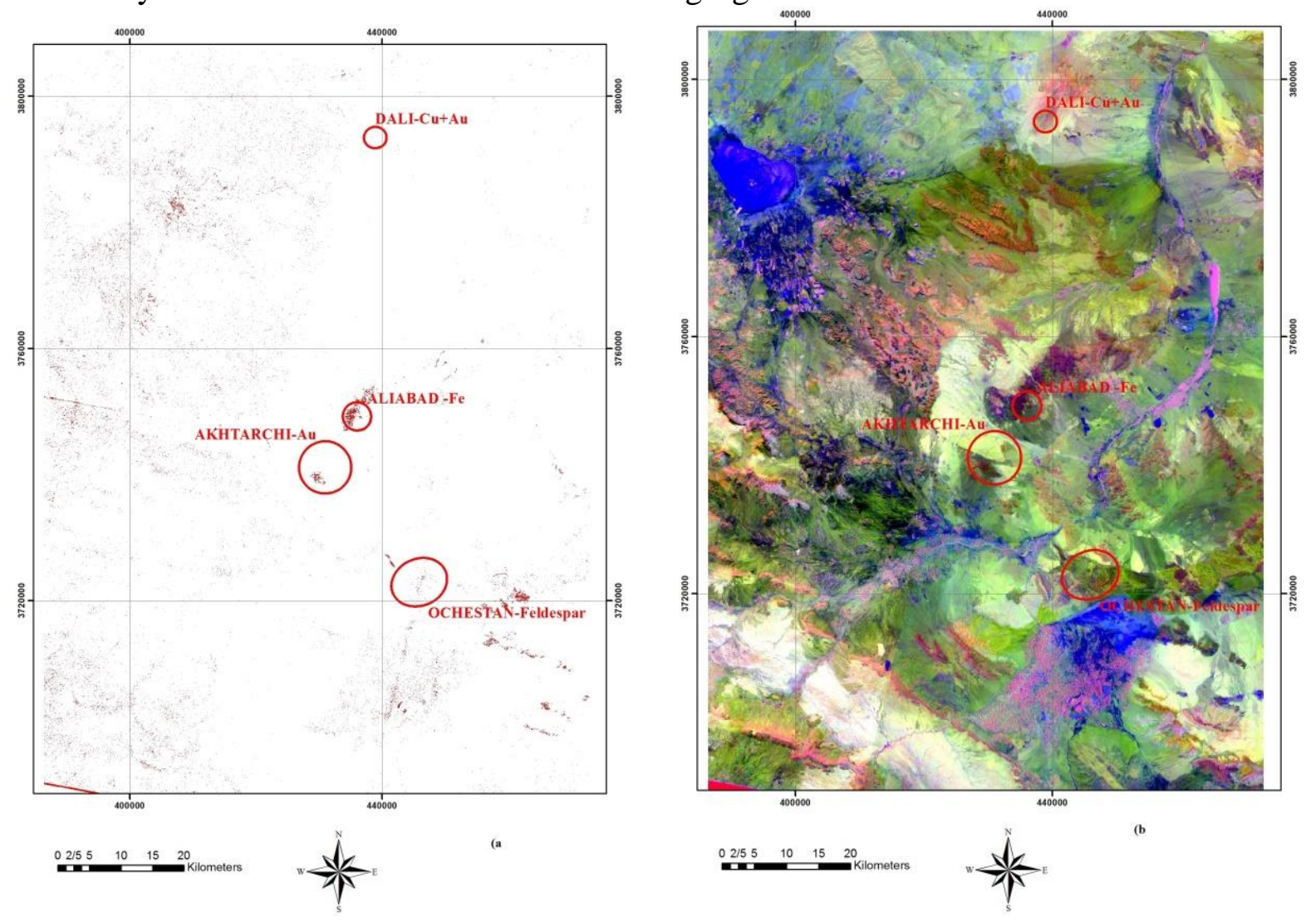

Figure 6. A) The image obtained from PC5 shows the alteration regions (red) and B) PCA123, indicating $70 \%$ of the entire changes in the image in three bands of 1,2, and 3

In addition to the above methods, new methods can be developed using combined methods. One of these methods is the combination of PCA and SAM methods, the result of which is shown in the figure 7. 


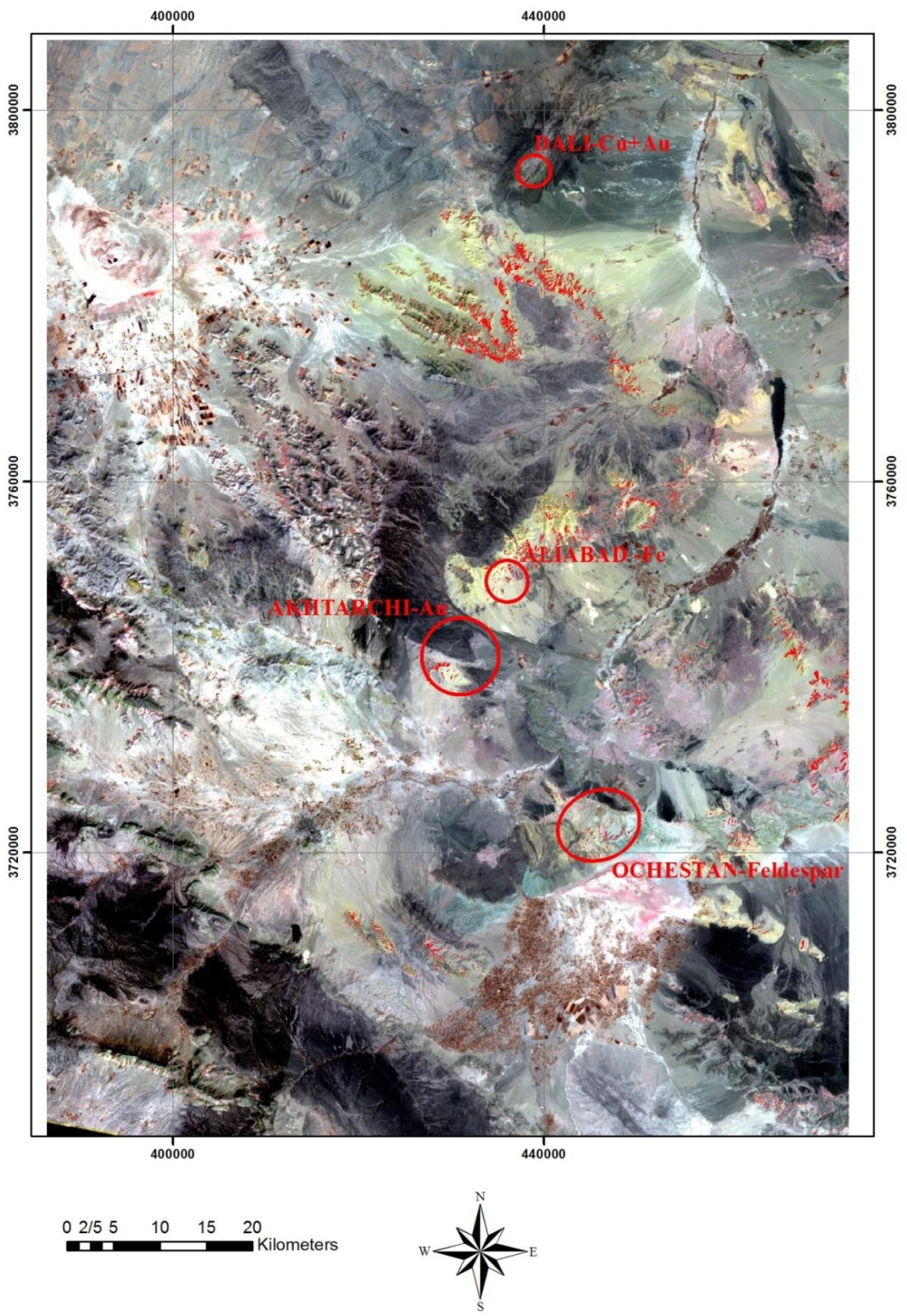

Figure 7- The result of combining PCA and SAM methods 


\section{CONCLUSION}

To investigate the status of the results, it was tried to identify important mines related to gold deposits in the region. Since the satellite data is related to 2001, the current situation of the mines was used to verify the results.

By comparing the maps obtained from different methods used in this research, it was found that SID, ECDC, SAM, and PCA methods and the combination of SAM and PCA methods are more accurate than other methods.

Based on the results, the combined method of PCA and angular mapper is introduced as an efficient and optimal method for detecting alterations in the region according to the conditions of the region. As can be seen in the above figures, Akhtarchi gold mine, Aliabad iron mine, Ochestan feldspar mine, and Dali gold and copper mines can be detected in the satellite data. Therefore, it is suggested that the points identified as anomalies in this method be used for preliminary explorations.

\section{ACKNOWLEDGMENT}

I would like to express my gratitude to professors Dr. Babaei, Dr. Dehghan, and Dr. Asadi who guided me in preparing this article. This paper is a part of the results obtained in the Ph.D. thesis of Mr. Alireza Payamani, which was conducted at the Islamic Azad University, Mahallat Branch.

\section{REFERENCIAS}

Azizi, H., Tarverdi, M.A. and Akbarpour, A., 2010. Extraction of hydrothermal alterations from ASTER SWIR datafrom east Zanjan, northern Iran, Advances in Space Research, v. 46, p. 99-109.

Azizi, H., Rsaouli, A.A. and Babaei, K., 2007. Using swir bands from aster for discrimination of hydrothermal altered minerals in the northwest of Iran (Se-Sanandaj city), Research journal of applied sciences, v. 2(96), p. 763-768.

Bedini, E., Van Der Meer, F. and Van Ruitenbeek, F., 2009. Use of HyMap imaging spectrometer data to map mineralogy in the Rodalquilar caldera, southeast Spain, Int. J. Remote, Sensing, v. 30, p. 327-348.

Boloki, M. and Poormirzaee, R., 2009. Using ASTER Image Processing for Hydrothermal Alteration and Key Alteration Minerals Mapping in Siyahrud area, Iran, International Journal of Geology, v. 3, p. 38-43.

Crosta, A. and De Souza Fliho, C., 2003. Targeting key alteration minerals in epithermal deposits in Patagonia, Argentina, using ASTER imagery and principal component analysis, International Journal of Remote Sensing, v. 21, p. 4233-4240.

Crosta, A.P. and Moore MCM, J., 1989. Enhancement of landsat thematic mapper imagery for residual soil mapping in SW Minas Gerais State Brazil: a prospecting case history in greenstone belt terrain, proceedings of the 9th thematic conference on remote sensing for exploration geology, Calgary, p. 1173-1187.

Di Tommaso,I.M., Rubinstein,N.,2006, Hydrothermal alteration mapping using ASTER data in the Infiernillo porphyry deposit, Argentina, Journal of Ore Geology Reviews, volume 29, pp. 1-16.

Dorothy Harper, 1976, EVE IN THE SKY: INTRODUCTION TO- REMOTE SENSING. Montreal: Multlscience Publications,. 164 pp.

Drury, S. 1987. Image Interpretation in Geology. London: Allen and Unwin, 243 pp.

ENVI 5 HELP

Fujisada, H., 1995, Design and performance of ASTER instrument, Proceedings of SPIE, International Society for Optical Engineering, v. 2583, p. 16-25.

Gomez, C., Delacourt, C., Allemand, P., Ledru, P. and Wackerle, R., 2004. Using ASTER remote sensing data set for geological mapping, in Namibia, Remote Sensing, v. 15, p. 125-142.

Gupta, R.P., 2003, Remote Sensing Geology, Second edition, Springer, Verlag, Berline, 656 p.

John C. Volesky, Robert J. Stern, Peter R. Johnson 2003. Geological control of massive sulfide mineralization in theNeoproterozoic Wadi Bidah shear zone, southwestern Saudi Arabia, inferences from orbital remote sensing and field studies. Precambrian Research 123 235-247.

Khalaj Masoumi, M., Lotfi, M., Memar Kouchebagh, A. and Khakzad, A., 2011. Hydrothermal alteration in Saghand 5 anomaly area using ASTER satellite imagery, Geosciences Research, No. 6, pp. 41-29 
Kruse, F.A., Boardman, J.W. and Huntington, J.F. 2003. Comparison of Airborne Hyperspectral Data and EO-1 Hyperion for Mineral Mapping, IEEE transactions on Geoscience and remote sensing, v. 41, p. 1388-1400.

Kruse, F. A., Boardman, J. W., Lefkoff, A. B., Heidebrecht,K. B., Shapiro, A. T., Barloon, P. J. and Goetz, A. F. H., 1993. the Spectral Image Processing System (SIPS). Interactive Visualization and Analysis of Imaging Spectrometer Data. Remote Sensing of Environment, 44: 145-163.

Mahvash Mohammadi, N., Hazarkhani, A., Maghsoudi, A 2012. Applying different methods of satellite image processing to identify and differentiate the alteration parts of the Khuni and Kal-e-Kafi regions (Isfahan province).

Masumi, F.A. and Ranjbar, H.A., 2011. Comparison between Airborne Geophysical and ASTER Data for Hydrothermal Alteration Mapping for Exploration of Copper Mineralization, Journal of Earth and Space Physics, No. 1, pp. 83-100.

Ninomiya,Y. and Fu., B., 2005. Detecting Lithology with Advanced Space-borne thermal Emission and Reflectance Radiometer (ASTER) multispectral thermal infrared "radiance-at-sensor" data. Journal of remote sensing of Environment, 99: 127-139.

Pour, B.A., Hashim, M. 2012. The application of ASTER remote sensing data to porphyry copper and epithermal gold deposits. Ore Geology Reviews. 44. 1-9.

Ranjbar, H., Shahriari, H. and Honarmand, M., 2004. Integration of ASTER and airborne geophysical data for exploration of copper mineralization, A case study of Sarcheshme area, Proceedings of 20th congress, International Society for Photogrammetery and Remote Sensing, Istanbul Turkey, v. 4, p. 701-706.

Sabins, F.F., 1999. "Remote sensing for mineral exploration", Ore Geology Reviews, v. 14, p. 157-183.

Segal, D. 1982. "Theoretical Basis for Differentiation of Ferric-Iron Bearing Minerals, Using Landsat MSS Data." Proceedings of Symposium for Remote Sensing of Environment, 2nd Thematic Conference on Remote Sensing for Exploratory Geology, Fort Worth, TX: 949-951.

Soe, M., Aung Kyaw, T. and Takashima, I., 2005. Application of remote sensing techniques on iron oxide detection from aster and landsat images of Tanintharyi Coastal Area Myanmar, Akita University, v. 26, p. 21-28.

Vincent, R.K., 1997. Fundamentals of Geological and Environmental Remote Sensing, 1st edition, Prentice Hall, v. $366,367 \mathrm{p}$.

Walfir, P.M., Filho, S. and Paradella, W.R., 2005, Use of RADARSAT-1 fine mode and Landsat-5 TM selective principal component analysis for geomorphological mapping in a macrotidal mangrove coast in the Amazon Region. Can. J, Remote Sensing, v. 31, p. 214-224.

Wolf, A., 2010 Using WorldView 2 Vis-NIR MSI Imagery to Support Land Mapping and Feature Extraction Using Normalized Difference Index Ratios. Unpublished report, Longmont, CO: DigitalGlobe.

XU Han-qiu , CHEN Ben-qing.2004. Remote sensing of the urban heat island and its changes in Xiamen City of SE China. Journal of Environmental Sciences Vol.16, No.2, pp .276-281. 